\title{
Lower photosynthetic capacity under higher spectral reflectance? The case of Actinidia polygama
}

\author{
Z.-X. WANG, G.-L. SHI, L. CHEN, D. SUN, P.-L. Xu², H.-Y. Qin², and J. AI* \\ Laboratory of Wild Fruit Physiology, College of Horticulture, Jilin Agricultural University, \\ Changchun, Jilin 130118, P.R. China ${ }^{1}$ \\ Laboratory of Special Wild Plant Physiology, Institute of Special Wild Economic Animal and Plant Science, \\ Chinese Academy of Agricultural Sciences, Changchun, Jilin 130112, P.R. China ${ }^{2}$
}

\begin{abstract}
The variegated leaves of Actinidia polygama exhibit a striking colour change during development. However, little is known whether the photosynthetic capacity of white leaves can be maintained. Therefore, spectrum properties, leaf structure, net photosynthetic rate $\left(\mathrm{P}_{\mathrm{N}}\right)$, and chlorophyll fluorescence in the green and white leaves were investigated. Although reflectance at $400-700 \mathrm{~nm}$ in white leaves was higher than that in green leaves, total chlorophyll content of white leaves was similar to that in green leaves. Palisade tissue cells of white leaves contained functional chloroplasts. Large intercellular spaces were observed between the epidermal and mesophyll cells and within the palisade tissue cell layer in white leaves. Both $\mathrm{P}_{\mathrm{N}}$ and the actual quantum yield of photosystem II in white leaves were similar to green leaves. At different leaf growth stages, $\mathrm{P}_{\mathrm{N}}$ of white leaves was about $88-100 \%$ of the $\mathrm{P}_{\mathrm{N}}$ of green leaves. The efficiency of electron move beyond $\mathrm{Q}_{\mathrm{A}}{ }^{-}$ $(\mathrm{ET} / \mathrm{TR})$ and the quantum yield of electron transport (ET/ABS) in white leaves was higher than in green leaves. In conclusion, photosynthetic capacity in white leaves of $A$. polygama showed two favorable characteristics during the whole sampling period: 1 ) despite a higher spectral reflectance in white leaves, $\mathrm{P}_{\mathrm{N}}$ of white leaves remained relatively high compared with green leaves; 2) the higher activity of photosystem II of white leaves enabled photosynthetic capacity maintenance.
\end{abstract}

Additional key words: anthocyanin, chlorophyll, fluorescence, net photosynthetic rate; photosystem II.

\section{Introduction}

In recent years, some studies have focused on functions of variegated leaves (Niu et al. 2014, Ranjan et al. 2014, Song et al. 2018), but only some on their photosynthetic capacity (Hughes et al. 2014). Previous studies reported that higher spectral reflectance usually lead to lower photosynthetic capacity, for example, red leaves reflect most of the red radiation (Karageorgou and Manetas 2006, Zhang et al. 2016). Furthermore, non-photosynthetic pigments compete with chlorophylls for photon capture, their presence entails a photosynthetic cost equal to the lost photons (Zeliou et al. 2009). In some plants, for example Begonia, Schismatoglottis calyptrata, and Arum italicum, a large proportion of leaves became white during development (Tsukaya et al. 2004, Zhang et al.
2009, Rocca et al. 2011). The photosynthesis is important physiological function of variegated leaves, especially of those appearing during juvenile stages (Solovchenko and Chivkunova 2011). However, until now, few studies have paid attention to maintenance of the photosynthetic capacity of the variegated leaves (Rocca et al. 2011).

Actinidia polygama is a species of deciduous woody vines of the genus Actinidia. It is distributed in cold areas in Asia (such as northeastern China). It is also cultivated widely in mixed forests. The plant is a very long-lived woody scrambling vine and creeper. It ultimately grows to $8-10 \mathrm{~m}$. A. polygama is the hardiest species in the genus, surviving temperatures of $-40{ }^{\circ} \mathrm{C}$ in the winter. Some of its leaves exhibit striking white color (Fig. 1). White leaf of $A$. polygama is different from other variegated plants, whose colour of adaxial and abaxial surface in variegated

Submitted 3 March 2020, last revision 9 May 2020, accepted 29 May 2020.

Abbreviations: ФPSII - quantum yield of photosystem II; ChINDI - chlorophyll normalized difference vegetation index; $\mathrm{ET}_{0} / \mathrm{ABS}_{-}$ quantum yield of electron transport; $\mathrm{ET}_{0} / \mathrm{TR}_{0}$ - efficiency of electron move beyond $\mathrm{Q}_{\mathrm{A}} ; \mathrm{P}_{\mathrm{N}}$ - net photosynthetic rate; $\mathrm{PPFD}$ - photosynthetic photon flux density; PSII - photosystem II.

Acknowledgments: We thank Dr. Hongyan Qin, Guangli Shi, and Ying Zhao (Laboratory of Special Wild Plant Physiology, Institute of Special Wild Economic Animal and Plant Science, Chinese Academy of Agricultural Sciences) for providing experimental assistance. This study was supported by the Natural Science Foundation of China (to ZXW, GLS, JA and CDJ, 31870673, 31571576) and the Central Public-interest Scientific Institution Basal Research Fund (1610342018007).

* Corresponding authors; e-mail: aijun1005@163.com 
leaves is homogeneous (Aluru et al. 2006, Kato et al. 2007). In A. polygama, variegated leaves are white on the adaxial surface, but the entire abaxial surface is green. Hence, white leaves of $A$. polygama are different from photobleaching and white mutants (for example Var variegation and reticulate mutants), which are mainly due to damage caused by reactive oxygen species (Takahashi et al. 2002, Naresh and Bai 2009, Uzarevic et al. 2011) and completely defective chloroplast development (Aluru et al. 2006, Liu et al. 2010, Lundquist et al. 2014). These latter kinds of mutation usually belong to lethal genotypes, and the lifespan of such leaves is very short. However, there are long time observations on white leaves of $A$. polygama showing that they can develop normally from Mid-June to September, and are, therefore probably not due to lethal genotypes. However, it is not clear whether photosynthetic function is retained in white leaves of A. polygama.

In order to assess the photosynthetic capacity of white leaves of the A. polygama, these were compared with green leaves with respect to leaf reflectance, leaf structure, net photosynthetic rate, and chlorophyll fluorescence parameters throughout the sampling period.

\section{Materials and methods}

Plants: Actinidia polygama (Sieb. et Zucc.) Planch. ex Maxim. plants were use for these experiments. The plants

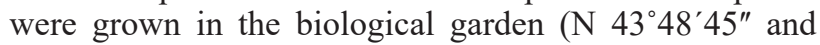
E $125^{\circ} 24^{\prime} 15^{\prime \prime}$ ) of Jilin Agricultural University, Changchun City, Jilin Province. The annual precipitation was $867 \mathrm{~mm}$ and the annual temperature range from $35^{\circ} \mathrm{C}$ and $-40{ }^{\circ} \mathrm{C}$ in the region. When the plants in the experimental area were in direct sunlight, they received natural irradiance of $1300-1400 \mu \mathrm{mol} \mathrm{m} \mathrm{m}^{-2} \mathrm{~s}^{-1}$ ). Measurements started in mid-June 2019, and the criteria for leaf selection were that the leaves had a similar dimension (about $15 \times 9 \mathrm{~cm}$ ) and a similar exposure to sunlight. Homogenous areas of the same leaves were measured during leaf development in each independent experiment.

Leaf reflectance was measured of five white and green intact leaves of different development stages with a bifurcated fiber optic cable and a leaf-clip of a Unispec SC Spectrometer (PP Systems, Amesbury, MA, USA). The Unispec $S C$ has a nominal spectral range from 350 to $1130 \mathrm{~nm}$ with approximately $3 \mathrm{~nm}$ nominal bandwidth (Xue et al. 2014). The leaf was irradiated from one side with a tungsten halogen lamp in the spectrometer using bifurcated fiber. The reflectance spectrum over the range $400-750 \mathrm{~nm}$ was analyzed. The following chlorophyll normalized difference vegetation index (ChlNDI), which can estimate relative chlorophyll content, was derived from spectral reflectance curves ( $\mathrm{R}$ denotes reflectance and the subscripts refer to specific spectral wavelength): ChlNDI $=\left(R_{750}-R_{705}\right) /\left(R_{750}+R_{705}\right)$ (Gitelson and Merzlyak 1994, Blackburn 1998).

Chlorophyll content: Ten leaf discs were excised using a standard hole punch, immediately sealed in pre-labeled aluminum envelopes and placed in liquid nitrogen. Tissues were stored at $-80{ }^{\circ} \mathrm{C}$ until analysis. Leaf discs were extracted in solvent mixture of acetone, methanol, and water $(80: 15: 5, \mathrm{v} / \mathrm{v} / \mathrm{v}$.). The chlorophyll content was measured at 663 and $645 \mathrm{~nm}$ using an UV-visible spectrophotometer UV-1601 (Shimadzu, Kyoto, Japan) according to Porra (2002). Total chlorophyll content was calculated by the formula (Total chlorophyll) $=(20.29 \times$ $\left.\mathrm{A}_{645}\right)$ - $\left(8.05 \times \mathrm{A}_{663}\right)$, in which $\mathrm{A}$ denotes the absorbance at the chlorophyll peaks (663 nm and $645 \mathrm{~nm})$.

Leaf structure and chloroplast ultrastructure: Sample preparation for semi-thin sections and transmission electron microscopy (TEM) was performed according to previously described methods (Konoplyova et al. 2008, Sheue et al. 2012). Small pieces of leaf $\left(1.0 \times 1.0 \mathrm{~mm}^{2}\right)$ from both white and green leaves were cut and fixed in $2.5 \%(\mathrm{~m} / \mathrm{v})$ glutaraldehyde in $0.1 \mathrm{M}$ sodium phosphate buffer (pH 7.3) overnight at $4{ }^{\circ} \mathrm{C}$. Semi-thin sections were stained with $1 \%(\mathrm{~m} / \mathrm{v})$ toluidine blue (Wang et al. 2015) and observed under a light microscope (ECLIPSE $80 i$, Nikon, Tokyo, Japan). Photomicrographs were taken using a Zeiss Axiolab (Tokyo, Japan) with a digital camera (Nikon DXM1200). Ultrathin sections were observed using a transmission electron microscope (TEM; JEM-1200EX; $J E O L$, Tokyo, Japan) at $80 \mathrm{kV}$.

Net photosynthetic rate $\left(\mathrm{P}_{\mathrm{N}}\right)$ was measured between 08:00 and 11:00 $\mathrm{h}$ (to avoid midday depression of photosynthesis) with a CIRAS-2 portable photosynthesis system (PP-Systems, Amesbury, USA). Photosynthetic photon flux density (PPFD) was gradually decreased stepwise using an integrated LED light source from 1200 to $0 \mu \mathrm{mol} \mathrm{m} \mathrm{m}^{-2} \mathrm{~s}^{-1}$ and $\mathrm{P}_{\mathrm{N}}$ at each PPFD was recorded when it was stable (usually $2-3 \mathrm{~min}$ ). The net photosynthetic rate was also measured in the field on intact leaves between 08:00 and 11:00 h on clear days with a CIRAS-2 (4 $\mathrm{cm}^{2}$ homogenous areas of the same leaves were measured during leaf development). Measurements were done under natural PPFD at $1300-1400 \mu \mathrm{mol} \mathrm{m}{ }^{-2} \mathrm{~s}^{-1}$, at $360 \mu \mathrm{mol} \mathrm{mol}{ }^{-1} \mathrm{CO}_{2}$, a leaf temperature about $30{ }^{\circ} \mathrm{C}$, a $70 \%$ relative humidity, and a flow rate of $196 \mathrm{~cm}^{3} \mathrm{~min}^{-1}$. Each measurement was completed within 2 - 3 min when steady-state photosynthesis had been achieved.

Chlorophyll fluorescence was measured with an FMS2 pulse-modulated fluorometer (Hansatech Instruments, King's Lynn, Norfolk, UK). The fluorescence measurement protocol was as follows: the light-adapted leaves were continuously irradiated by actinic radiation from the FMS 2 light source. The steady-state fluorescence level $\left(\mathrm{F}_{\mathrm{s}}\right)$ and the maximum fluorescence in the light-adapted state $\left(\mathrm{F}_{\mathrm{m}}{ }^{\prime}\right)$ during exposure to different PPFDs were measured (Jiang et al. 2005). The PPFDs were set in the order of 2100 , 1 600, 1 200, 900, 600, 400, 300, 200, 150, 100, 70, 50, 25,15 and $0 \mu \mathrm{mol} \mathrm{m} \mathrm{m}^{-2} \mathrm{~s}^{-1}$ to obtain ФPSII-PPFD response curves. The ФPSII was calculated as $\left(\mathrm{F}_{\mathrm{m}}{ }^{\prime}-\mathrm{F}_{\mathrm{s}}\right) / \mathrm{F}_{\mathrm{m}}$ ', where ФPSII is quantum yield of photosystem II.

During leaf development, leaves were sampled at predawn (3:00 - 5:00). Chlorophyll $a$ fluorescence transience 
(OJIP) was measured with a plant efficiency analyzer (Pocket-PEA, Hansatech Instruments). The saturating red radiation of $3000 \mu \mathrm{mol} \mathrm{m} \mathrm{m}^{-2} \mathrm{~s}^{-1}$ was produced by an array of four light-emitting diodes (LEDs, peak $650 \mathrm{~nm}$ ). Fluorescent signals were recorded within a time scan from $10 \mu \mathrm{s}$ to $1 \mathrm{~s}$ with a data acquisition rate of 100 readings $\mathrm{ms}^{-1}$ for the first $2 \mathrm{~ms}$, and 1 reading $\mathrm{ms}^{-1}$ after $2 \mathrm{~ms}$. All measurements were performed on adaxial surface of fully dark-adapted $(1 \mathrm{~h})$ leaves. Fluorescent transients were analyzed with the JIP-test (Strasser and Strasser 1995, Strasser 1997, Van Heerden et al. 2007). The description and calculation of parameters are given according to Zhang et al (2012). The JIP-test defines the maximal (subscript "0") energy fluxes in the energy cascade for the events absorption (ABS), trapping $\left(\mathrm{TR}_{0}\right)$, and electron transport $\left(\mathrm{ET}_{0}\right)$ (Christen et al. 2007). The efficiency of electron move beyond $\mathrm{QA}^{-}, \mathrm{ET}_{0} / \mathrm{TR}_{0}=1-\mathrm{V}_{\mathrm{J}}$; quantum yield for electron transport, $\mathrm{ET}_{0} / \mathrm{ABS}=\left\{1-\left(\mathrm{F}_{0} / \mathrm{F}_{\mathrm{m}}\right)\right\} \cdot \mathrm{ET}_{0} / \mathrm{TR}_{0}$.

Statistical analysis was performed with the $S A S$ software (JMP 6.0, SAS Institute, Cary, USA). For data sets with parametric distribution, significant differences among means of green and white were determined using the Student's $t$-test $(P<0.01)$. Leaf reflection spectra were calculated and are presented as the average of five independent measurements. Chlorophyll content was calculated and is presented as the average of three independent measurements. Gas exchange data were calculated as the average of individual measurements of three leaves. The photosynthetic light response curve data and light responses of quantum yield of photosystem II represent the means of individual measurements of three leaves. Chlorophyll $a$ fluorescent parameters represent means individual measurements of five leaves.
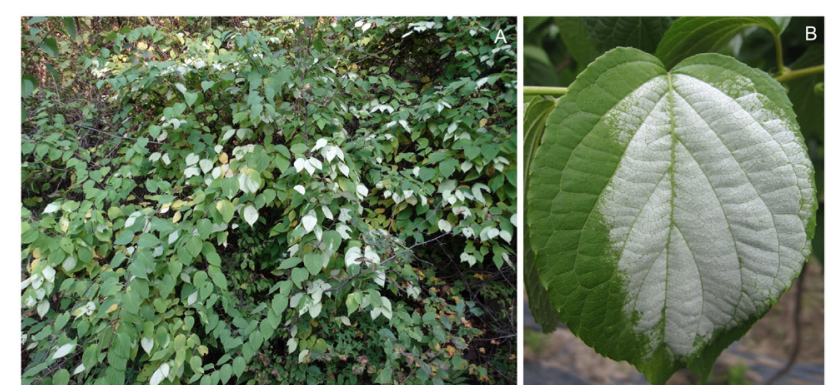

Fig. 1. An Actinidia polygama plant with white leaves $(A)$ and a detail of a white leaf $(B)$.

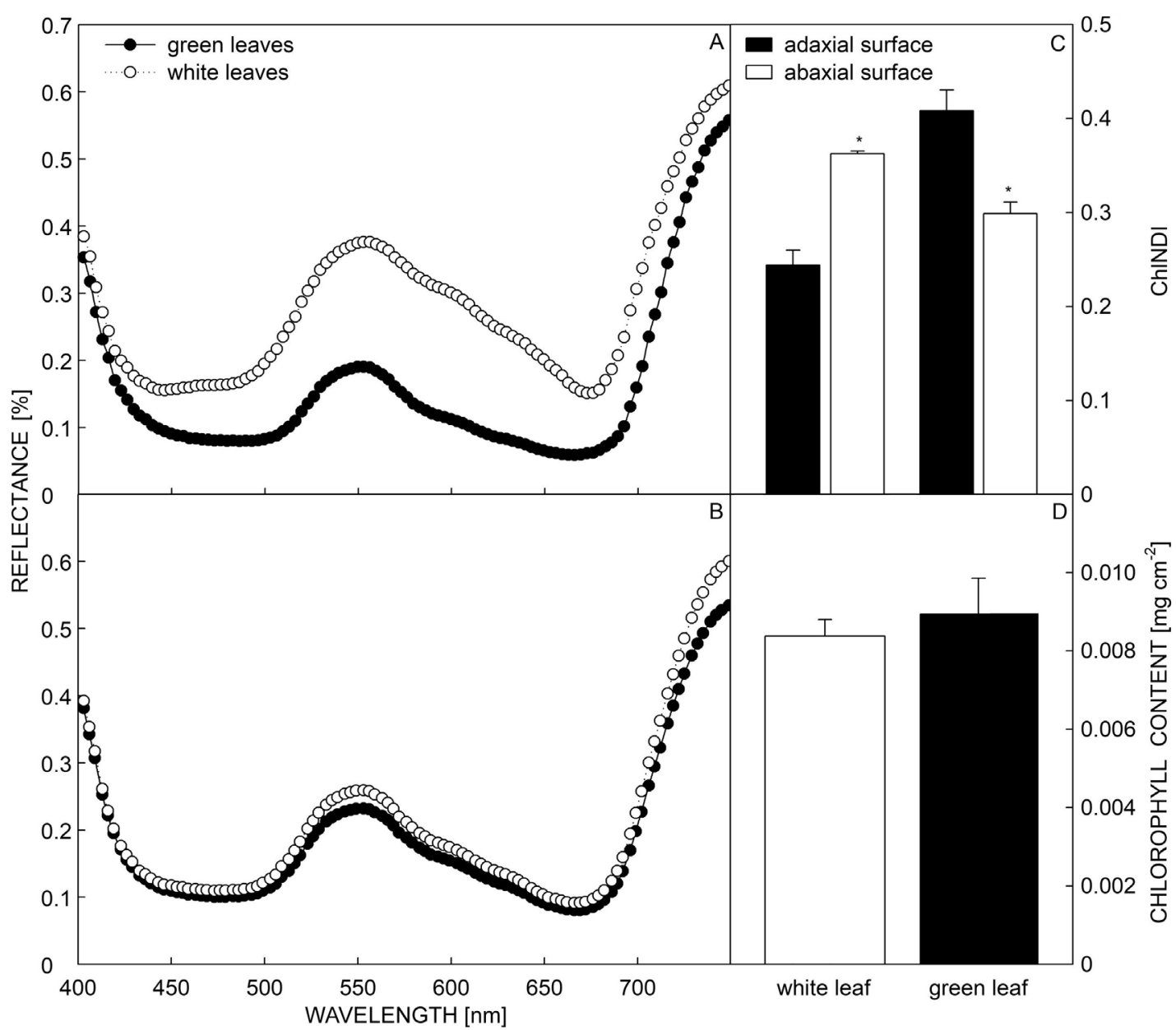

Fig. 2. Different reflectance spectra of Actinidia polygama white and green leaves on the adaxial $(A)$ and abaxial $(B)$ surfaces, chlorophyll normalized difference vegetation index (ChINDI) $(C)$, and total chlorophyll content $(D)$. Means \pm SEs, $n=5(A-C)$ or $3(D)$; Asterisks indicate significant differences $(P<0.05)$ between adaxial and abaxial surfaces. 


\section{Results}

The reflectance spectra over the range $400-750 \mathrm{~nm}$ in leaves of different colour were analyzed (Fig. 2). Reflectance was more pronounced in white leaves than in green leaves. On adaxial surfaces, the reflectance of
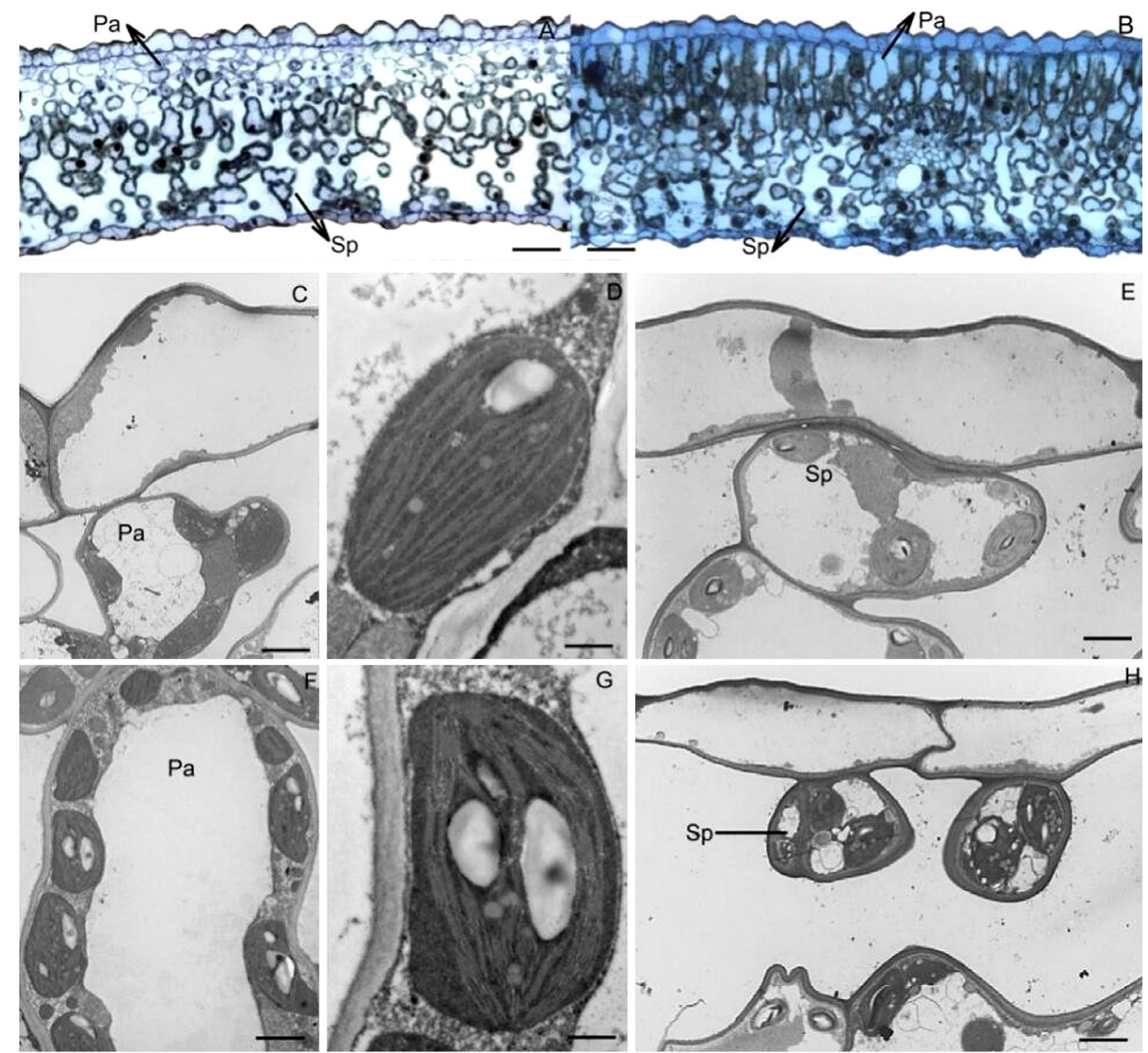

Fig. 3. Anatomical and ultrastructural features of green and white leaves of Actinidia polygama. Transverse sections from variegated $(A)$ and green $(B)$ leaves. Ultrastructure of white leaves: palisade tissue cell $(C)$, chloroplast $(D)$, spongy tissue cell $(E)$. Ultrastructure of green leaves: palisade tissue cell $(F)$, chloroplast $(G)$, spongy tissue cell $(H)$. Pa - palisade tissue; Sp - spongy tissue. Scale bars: $50 \mu \mathrm{m}$ in $A, B, 500 \mathrm{~nm}$ in $D, G, 2 \mu \mathrm{m}$ in $C, E, F, H$.

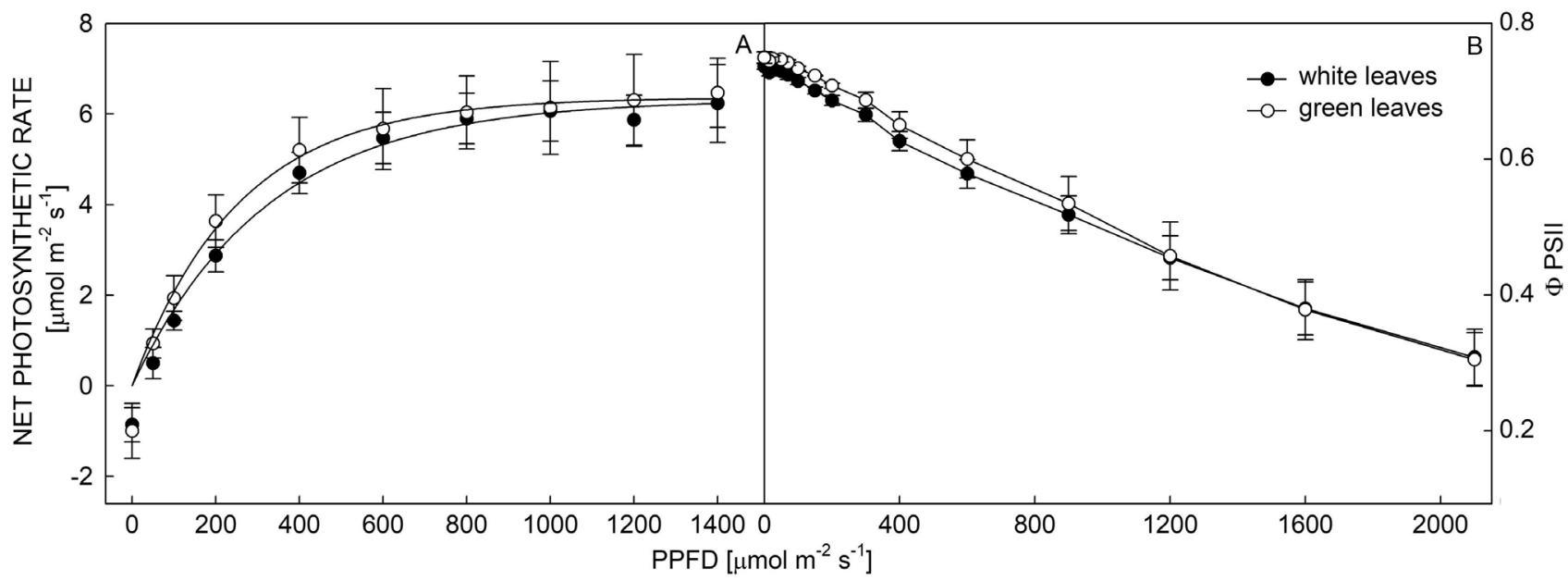

Fig. 4. Responses of net photosynthetic rate and the actual quantum yield of photosystem II (ФPSII) to photosynthetic photon flux density (PPFD) in white and green leaves of Actinidia polygama seedlings. Means \pm SEs, $n=3$. 
white leaves was higher than that of green leaves, nearly $15-61 \%$ of the incident radiation was reflected (Fig. $2 A$ ). However, reflectance on abaxial surfaces of white leaves was similar to that of green leaves (Fig. 2B). Although ChlNDI of white leaves was lower than of green leaves on the adaxial surface, the trend was contrary on the abaxial surface (Fig. 2C). Total chlorophyll content of white and green leaves was similar (Fig. 2D).

The anatomy of green and white leaves was
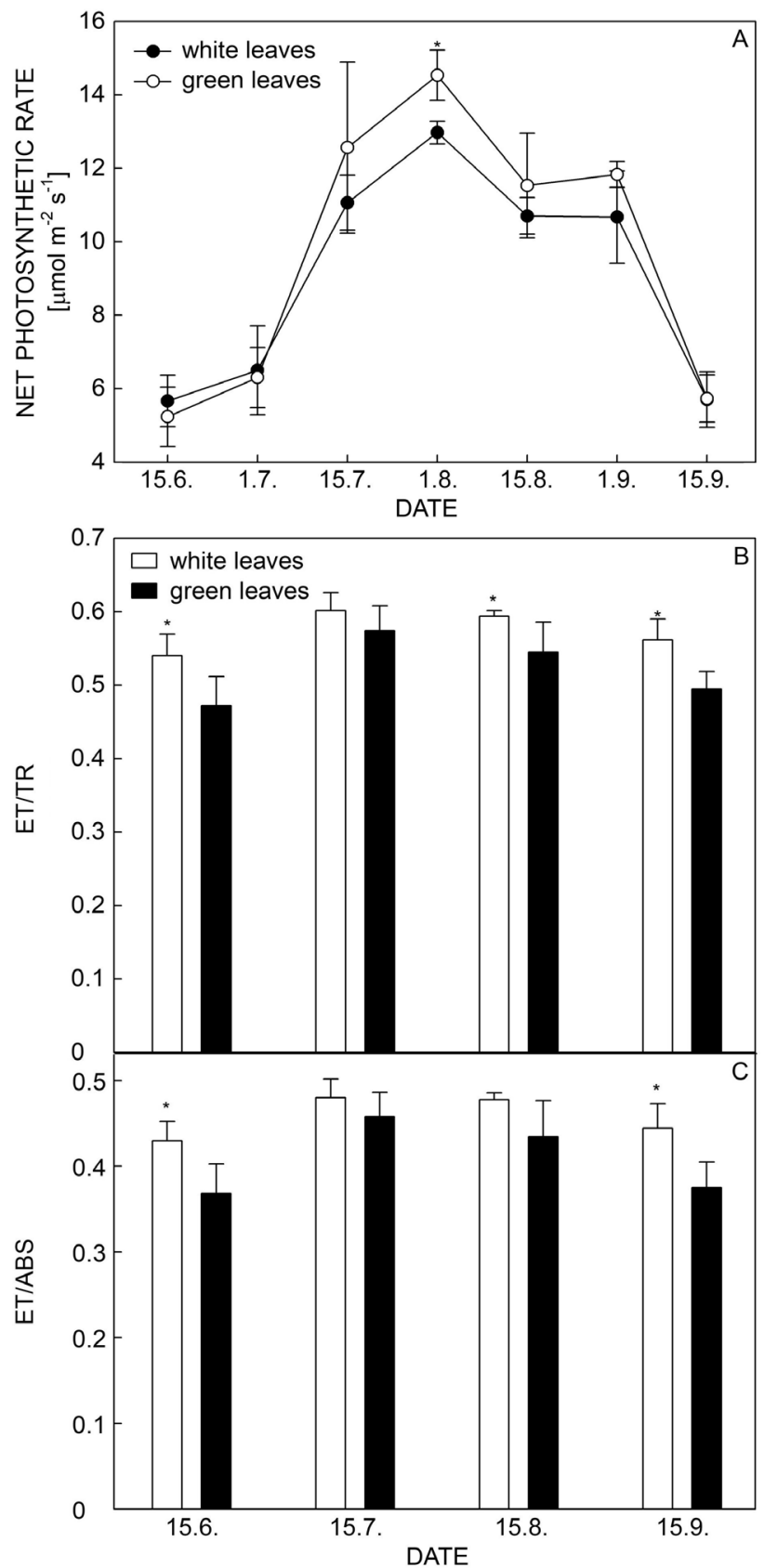

Fig. 5. Net photosynthetic rate $(A)$ and chlorophyll fluorescence parameters $\mathrm{ET}_{0} / \mathrm{TR}_{0}(B)$ and $\mathrm{ET}_{0} / \mathrm{ABS}(C)$ in green and white leaves of Actinidia polygama at different dates during a vegetation season. For abbreviations - see Materials and methods. Means \pm SEs, $n=5$. Asterisks indicate significant differences $(P<0.05)$ between white and green leaves. significantly different (Fig. 3). In white leaves, 1 - 3 layers of irregular cells were observed (Fig. $3 A$ ), rather than the typical palisade tissue. However, palisade tissue of green leaf consisted of 2 - 3 layers of packed and elongated cylindrical cells (Fig. $3 B$ ) that were in tight contact with the adaxial epidermis. Intercellular spaces were observed between the epidermal and the mesophyll cells or within the mesophyll cell layer in white leaves (Fig. $3 A$ ). In cross-section, spongy tissue in white leaves was thicker than in green leaves (Fig. $3 A, B$ ). In addition, chloroplast development in palisade and spongy parenchyma cells in white (Fig. 3C-E) and green (Fig. $3 F-H$ ) leaves was normal, starch grain and abundant thylakoid membranes were observed in chloroplasts.

As shown in Fig. $4 A$, the light-saturated $\mathrm{P}_{\mathrm{N}}$ of white and green leaves had no significant differences. As shown in Fig. $4 B$, ФPSII decreased gradually with irradiance increase and $\Phi$ PSII of white leaves was similar to that of green leaves. For total $\mathrm{P}_{\mathrm{N}}$ during the whole sampling period, the light-saturated $\mathrm{P}_{\mathrm{N}}$ of green and white leaves increased gradually with leaf development and $\mathrm{P}_{\mathrm{N}}$ of white leaves was about $88-100 \%$ of that in green leaves; there were no statistically significant difference (Fig. $5 A$ ), and $\mathrm{P}_{\mathrm{N}}$ of white leaves was equal to $93 \% \mathrm{P}_{\mathrm{N}}$ of green leaves.

Much more pronounced differences were found between white and green leaves in the parameters derived from analysis of the fluorescence transient curves according to the JIP-test. During leaf development, ET/TR and ET/ABS of white leaves were higher than those of green leaves (Fig. 5B,C).

\section{Discussion}

Generally speaking, variegated leaves usually have lower photosynthetic rate than green leaves (Burger and Edwards 1996, Hughes et al. 2005, Song et al. 2018). Photosynthetic capacity of variegated leaves in Arabidopsis mutant is almost completely lost, which was due to chlorophyll absence (Yu et al. 2011, Sheue et al. 2012, Lundquist et al. 2014, Song et al. 2018). In natural variegated plants, for example Ficus pumila cv. Sonny and Saururus chinensis, photosynthetic capacity decreased by $50 \%$ even more. However, our study showed that $\mathrm{P}_{\mathrm{N}}$ and ФPSII of white leaves in A. polygama was similar to green leaves, although spectral reflectance from adaxial surface of white leaves was two-fold higher than that of green leaves. Why variegated leaves can maintain a rather high $\mathrm{P}_{\mathrm{N}}$ ? White leaves of $A$. polygama may utilizes two mechanisms for maintaining photosynthetic capacity. First, functional chloroplasts were observed in palisade tissue cells of white leaves. In previous studies, photosynthetic capacity decrease in variegated leaves was mainly due to chlorophyll deficiency (Sheue et al. 2012, Song et al 2018). For example, palisade tissue cells of variegated leaves do not contain functional chloroplasts in S. chinensis (Song et al 2018). However, our results show that the total chlorophyll content had no significant difference although the relative chlorophyll content of white leaves was lower than of green leaves at the adaxial surface. Moreover, 
the higher photosynthetic activity in white leaves might further maintain photosynthetic capacity.

The parameters derived from JIP-testing can be useful indicators for evaluation of photosynthetic capacity of leaves (Wen et al. 2005, Mathur et al. 2011). During leaf development, $\mathrm{ET}_{0} / \mathrm{TR}_{0}$ and $\mathrm{ET}_{0} / \mathrm{ABS}$ in white leaves was higher than in green leaves (Fig. 5). The higher efficiency of electron transport $\left(\mathrm{ET}_{0} / \mathrm{ABS}\right.$ and $\left.\mathrm{ET}_{0} / \mathrm{TR}_{0}\right)$ maximized the photosynthetic ability of white leaves.

\section{References}

Aluru, M.R., Yu, F., Fu, A., Rodermel, S.: Arabidopsis variegation mutants: new insights into chloroplast biogenesis. - Environ. exp. Bot. 57: 1871-1881, 2006.

Blackburn, G.A.: Spectral indices for estimating photosynthetic pigment concentrations: a test using senescent tree leaves. Int. J. Remote Sensing 19: 657-675, 1998.

Burger, J., Edwards, G.E.: Photosynthetic efficiency, and photodamage by UV and visible radiation, in red versus green leaf Coleus varieties. - Plant Cell Physiol. 37: 395-399, 1996.

Christen D., Schonmanna S., Jermini M., Strasser R.J., Defago G. Characterization and early detection of grapevine (Vitis vinifera) stress responses to esca disease by in situ chlorophyll fluorescence and comparison with drought stress. - Environ. exp. Bot. 60: 504-514, 2007.

Gitelson, A.A., Merzlyak, M.N.: Spectral reflectance changes associated with autumn senescence of Aesculus hippocastanum L. leaves: spectral features and relation to chlorophyll estimation. - J. Plant Physiol. 143: 286-292, 1994.

Hughes, N.M., Carpenter, K.L., Keidel, T.S., Miller, C.N., Waters, M.N., Smith, W.K.: Photosynthetic costs and benefits of abaxial versus adaxial anthocyanins in Colocasia esculenta 'Mojito'. - Planta 240: 971-981, 2014.

Hughes, N.M., Neufeld, H.S., Burkey, K.O.: Functional role of anthocyanins in high-light winter leaves of the evergreen herb Galax urceolata. - New Phytol. 168: 575-587, 2005.

Jiang, C., Li, P., Gao, H., Zou, Q., Jiang, G., Li, L.: Enhanced photoprotection at the early stages of leaf expansion in fieldgrown soybean plants. - Plant Sci. 168: 911-919, 2005.

Karageorgou, P., Manetas, Y.: The importance of being red when young: anthocyanins and the protection of young leaves of Quercus coccifera from insect herbivory and excess light. Tree Physiol. 26: 613-621, 2006.

Kato, Y., Miura, E., Matsushima, R., Sakamoto, W.: White leaf sectors in yellow variegated 2 are formed by viable cells with undifferentiated plastids. - Plant Physiol. 144: 952-960, 2007.

Konoplyova, A., Petropoulou, Y., Yiotis, C., Psaras, G.K., Manetas, Y.: The fine structure and photosynthetic cost of structural leaf variegation. - Flora 203: 653-662, 2008.

Liu, X.Y., Rodermel, S.R., Yu, F.: A var2 leaf variegation suppressor locus, SUPPRESSOR OF VARIEGATION3, encodes a putative chloroplast translation elongation factor that is important for chloroplast development in the cold. BMC Plant Biol. 10: 287-306, 2010.

Lundquist, P.K., Rosar, C., Bräutigam, A., Weber, A.P.M.: Plastid signals and the bundle sheath: mesophyll development in reticulate mutants. - Mol. Plants 7: 14-29, 2014.

Mathur, S., Jajoo, A., Mehta, P., Bharti, S.: Analysis of elevated temperature-induced inhibition of photosystem II using chlorophyll a fluorescence induction kinetics in wheat leaves (Triticum aestivum). - Plant Biol. 13: 1-6, 2011.

Naresh, K., Bai, K.: Photo-oxidative stress in coconut seedlings: early events to leaf scorching and seedling death. - Braz. J.
Plant Physiol. 21: 223-232, 2009.

Niu, Y., Chen, G., Peng, D.L., Song, B., Yang, Y., Li, Z.M., Sun, H.: Grey leaves in an alpine plant: a cryptic colouration to avoid attack? - New Phytol. 203: 953-963, 2014.

Porra, R.J.: The chequered history of the development and use of simultaneous equations for the accurate determination of chlorophyll $a$ and $b$. - Photosynth. Res. 73: 149-156, 2002.

Ranjan, S., Singh, R., Singh, M., Pathre, U.V., Shirke, P.A.: Characterizing photoinhibition and photosynthesis in juvenile-red versus mature-green leaves of Jatropha curcas L. - Plant Physiol. Biochem. 79: 48-59, 2014.

Rocca, N.L., Rascio, N., Pupillo, P.: Variegation in Arum italicum leaves. A structural-functional study. - Plant Physiol. Biochem 49: 1392-1398, 2011.

Sheue, C.R., Pao, S.H., Chien, L.F., Chesson, P., Peng, C.I.: Natural foliar variegation without costs? The case of Begonia. - Ann. Bot. 109: 1065-1074, 2012.

Solovchenko, A.E., Chivkunova, O.B.: Physiological role of anthocyanin accumulation in common hazel juvenile leaves. Russ. J. Plant Physiol. 58: 674-680, 2011.

Song, B., Stöcklin, J., Armbruster, W.S., Gao, Y., Peng, D., Sun, H.: Reversible colour change in leaves enhances pollinator attraction and reproductive success in Saururus chinensis (Saururaceae). - Ann. Bot. 121: 641-650, 2018.

Strasser, B.J.: Donor side capacity of photosystem II probed by chlorophyll $a$ fluorescence transients. - Photosynth. Res. 52: 147-155, 1997.

Strasser, B.J., Strasser, R.J.: Measuring Fast Fluorescence Transients to Address Environmental Questions: The JIP Test. - Kluwer Academic Publisher, Dordrecht 1995.

Takahashi, S., Tamashiro, A., Sakihama, Y., Yamamoto, Y., Kawamitsu, Y., Yamasaki, H.: High-susceptibility of photosynthesis to photoinhibition in the tropical plant Ficus microcarpa L. f. cv. Golden Leaves. - BMC Plant Biol. 4: $1-8,2002$

Tsukaya, H., Okada, H., Mohamed, M.: A novel feature of structural variegation in leaves of the tropical plant Schismatoglottis calyptrate. - J. Plant Res. 117: 477-480, 2004.

Užarević, Z., Štolfa, I., Parađiković, N., Cesar, V., Lepeduš, H.: Physiology and biochemistry of leaf bleaching in prematurely aging maple (Acer saccharinum L.) trees: I. Hydrogen peroxide level, antioxidative responses and photosynthetic pigments. - Acta bot. croat. 70: 121-132, 2011.

Van Heerden, P.D.R., Swanepoel, J.W., Kruer, G.H.J.: Modulation of photosynthesis by drought in two desert scrub species exhibiting C-3-mode $\mathrm{CO}_{2}$ assimilation. - Environ exp. Bot. 61: 124-136, 2007.

Wang, Z.X., Fan, S.T., Chen, L., Zhao, Y., Yang, Y.M., Ai, J., Li, X.Y., Liu, Y.X., Qin, H.Y.: Actinidia kolomikta leaf colour and optical characteristics. - Biol. Plant. 59: 767-772, 2015.

Wen, X.G., Qiu, N.W., Lu, Q.T., Lu, C.M.: Enhanced thermotolerance of photosystem II in salt-adapted plants of the halophyte Artemisia anethifolia. - Planta 220: 486-497, 2005.

Xue, Z., Gao, H., Zhao, S.: Effects of cadmium on the photosynthetic activity in mature and young leaves of soybean plants. - Environ. Sci. Pollut. Res. 57: 587-590, 2014.

Yu, F., Park, S.S., Liu, X.Y., Foudree, A., Fu, A.G., Powikrowska, M., Khrouchtchova, A., Jensen, P.E., Kriger, J.N., Gray, G.R., Rodermel, S.R.: SUPPRESSOR OF VARIEGATION4, a new var2 suppressor locus, encodes a pioneer protein that is required for chloroplast biogenesis. - Mol. Plants 4: 229-240, 2011.

Zeliou, K., Manetas, Y., Petropoulou, Y.: Transient winter leaf reddening in Cistus creticus characterizes weak (stress- 
sensitive) individuals, yet anthocyanins cannot alleviate the adverse effects on photosynthesis. - J. exp. Bot. 60: 30313042, 2009.

Zhang, L.G., Wei, Q., Wu, W.J., Cheng, Y.X., Hu, G.Z., Hu, F.H., Sun, Y., Zhu, Y., Sakamoto, W., Huang, J.: Activation of the heterotrimeric G protein a-subunit GPA1 suppresses the ftsh-mediated inhibition of chloroplast development in Arabidopsis. - Plant J. 58: 1041-1053, 2009.
Zhang, Z.S., Li, G., Gao, H.Y., Zhang, L.T., Yang, C.: Characterization of photosynthetic performance during senescence in stay-green and quick-leaf-senescence Zea mays L. inbred lines. - PloS ONE 7: 1-10, 2012.

Zhang, T.J., Chow, W.S., Liu, X.T., Zhang, P., Liu, N., Peng, C.L.: A magic red coat on the surface of young leaves: anthocyanins distributed in trichome layer protect Castanopsis fissa leaves from photoinhibition. - Tree Physiol. 36: 1296-1306, 2016. 